RETRACTIONS

\title{
Androgen activates PEG10 to promote carcinogenesis in hepatic cancer cells
}

X Jie, C Lang, Q Jian, L Chaoqun, Y Dehua, S Yi, J Yanping, X Luokun, Z Qiuping, W Hui, G Feili, J Boquan, J Youxin and T Jinquan

Oncogene (2011) 30, 2798; doi:10.1038/onc.2011.66

Retraction to: Oncogene (2007) 26, 5741-5751; doi:10.1038/

sj.onc.1210362; published online 19 March 2007

This paper has been retracted.

\section{Selectively frequent expression of CXCR5 enhances resistance to apoptosis in $\mathrm{CD8}^{+} \mathrm{CD34}^{+} \mathrm{T}$ cells from patients with $\mathrm{T}$-cell-lineage acute lymphocytic leukemia}

Z Qiuping, X Jie, J Youxin, W Qun, J Wei, L Chun, W Jin, L Yan, H Chunsong, Y Mingzhen, G Qingping, L Qun, Z Kejian, S Zhimin, L Junyan and T Jinquan

Oncogene (2011) 30, 2798; doi:10.1038/onc.2011.67

Retraction to: Oncogene (2005) 24, 573-584; doi:10.1038/

sj.onc.1208184; published online 6 December 2004

This paper has been retracted. 